\title{
Analysis of Production and Release of Products and Reserves for their Increase
}

\author{
Sokolova I.N. ${ }^{1, *}$, Sokolova A.V. ${ }^{2}$ \\ 1 Associate Professor of Accounting, Analysis and Audit, Kalashnikov Izhevsk State Technical University \\ ${ }^{2}$ student 2 course, International financial faculty, Financial University under the government of the Russian Federation
}

\begin{abstract}
The article is devoted to the analysis of the main indicators of the activity of the manufacturing enterprise - the production and sale of products. The structure of sales of products by types of products, by sales markets, implementation of the plan for production and sale of products, changes in the balance of unrealized products is analyzed. The structure of sales of products by types of products, by sales markets, implementation of the plan for production and sale of products, changes in the balance of unrealized products is analyzed. Much attention is paid to the analysis of certain types of unrealized products, the reasons for their occurrence. In the process of analyzing the implementation of the plan, special attention is paid to the analysis of rhythmicity, since irregularity generates downtime of equipment, transport, loss of working hours, the need for overtime, worsens all economic indicators. Based on the analysis of output and sales of products, measures have been developed to increase them, in particular: expanding sales markets, improving the quality of products, increasing the rhythms of production and shipment of products, strengthening economic relations with enterprises of the service and distribution network, observance of contractual discipline. The implementation of these measures will lead to the opening of the company's new development prospects, to increase the competitiveness of products, will allow further expansion of production, create a favourable investment climate, will be the key to successful cooperation with Russian and foreign companies.
\end{abstract}

Keywords: production, sales of products, sales markets, rhythm, implementation of the plan, unrealized products, factors, competitiveness, product quality, reserves of sales increase.

The realization process completes the circuit of the enterprise's economic resources, which allows it to fulfil its obligations to the state budget, the bank for loans, workers and employees, suppliers and reimburse production costs. Failure to implement the sales plan causes a slowdown in the turnover of working capital, fines for non-fulfilment of contractual obligations to buyers, delays payments, and worsens the financial position of the enterprise.

Consequently, the volumes of production and sales of products are the main indicators of the activity of the production enterprise, on which their competitiveness and overall effective functioning depend.

Thus, the purpose of the article is to analyze the release and sale of products and determine the reserves for their increase. The object of the study is the limited liability company "United Automobile Group".

To study the factors affecting the sales of "OAG" LLC, we will begin with the analysis of the priority of sales of the model line. Thus, the traditional model for the company is the LADA GRANTA car, whose share in the shipment volume is $94.60 \%$. Consequently, it is suitable to analyze the influence of various factors on the effectiveness of selling products using the example of this model. 
Tab. 1: Structure of sales of cars.

\begin{tabular}{|l|l|l|}
\hline Model & $\begin{array}{l}\text { Shipment amount, } \\
\text { thousand rubles }\end{array}$ & $\begin{array}{l}\text { Share in the sales } \\
\text { structure, \% }\end{array}$ \\
\hline LADA GRANTA & 22175883,60 & 94,60 \\
\hline NISSAN Sentra & 1264155,84 & 5,40 \\
\hline Total: & 23440039,44 & 100,00 \\
\hline
\end{tabular}

Tab. 2: Analysis of sales priorities by federal districts.

\begin{tabular}{|l|l|l|}
$\begin{array}{l}\text { Name of the federal } \\
\text { district }\end{array}$ & $\begin{array}{l}\text { Annual sales, } \\
\text { thousand rubles }\end{array}$ & $\begin{array}{l}\text { Share in the sales } \\
\text { structure,\% }\end{array}$ \\
\hline Central & 4947841,50 & 22,31 \\
\hline Siberian & 4638073,89 & 20,91 \\
\hline Privolzhsky & 3986617,00 & 17,98 \\
\hline Southern & 2512136,04 & 11,34 \\
\hline Uralian & 2347085,45 & 10,58 \\
\hline North-Caucasian & 2029724,50 & 9,15 \\
\hline Northwestern & 1456755,62 & 6,57 \\
\hline Far Eastern & 257650,00 & 1,16 \\
\hline Total: & 22175884,00 & 100 \\
\hline
\end{tabular}

Next, we will analyze the priority of regional markets - ranking in descending order.

Table 2 shows that the priority markets for the organization are the Central, Siberian and Volga federal districts. This is due to the large number of car dealers there.

Tab. 3: Production, sales and residuals plan for the LADA GRANTA.

\begin{tabular}{|l|l|l|l|l|l|l|l|}
\hline Balance at beginning of year & \multicolumn{3}{l|}{ Production plan } & \multicolumn{2}{l|}{ Realization plan } \\
\hline Units & Thousand Roubles & Units & Thousand Roubles & Units & Thousand Roubles & Units & Thousand Roubles \\
\hline 2422 & 780271,52 & 76100 & 24516376 & 75187 & 24222244 & 3335 & 1074403,60 \\
\hline
\end{tabular}

Tab. 4: Factor analysis of the implementation of the plan for the sale of cars of model LADA GRANTA.

\begin{tabular}{|c|c|c|c|c|}
\hline Indicators & Plan & Fact & $\begin{array}{l}\text { Deviation from plan } \\
\text { In thousand rubles }\end{array}$ & In $\%$ to the plan \\
\hline Sales of products & 24222244,00 & 22175884,00 & $-2046360,00$ & -9 \\
\hline Production Output & 24516376,00 & 23526700,48 & $-989675,52$ & -5 \\
\hline Change in balances of unrealized products & $+294132,00$ & $+1350816,48$ & $+1056684,48$ & +4 \\
\hline
\end{tabular}

Tab. 5: Analysis of the types of unrealized products of the LADA GRANTA model.

\begin{tabular}{|c|c|c|c|}
\hline Types of unrealized products & Plan, thousand rubles & Fact, thousand rubles & Deviation from the plan, thousand rubles \\
\hline Finished goods in storage & - & 263526,90 & $+263526,90$ \\
\hline Goods shipped, payment terms of which have not come yet & 294132,00 & 602438,78 & $+308306,78$ \\
\hline Goods shipped but not paid in time by buyers & - & 481951,40 & $+481951,40$ \\
\hline Commodity storage of buyers & - & 2899,40 & $+2899,40$ \\
\hline Total unrealized production & 294132,00 & 1350816,48 & $+1056684,48$ \\
\hline
\end{tabular}

Next, we will analyze the implementation of the sales plan for the following tasks:

Establishment of the validity of the indicator of the business plan for the sale of products;

Determination of the degree of implementation of the plan for the volume and range of products sold;

- Calculation of the influence of individual factors on the amount of deviation of the actual volume of sales from the planned one;

Exploration of reserves of further increase in sales and ways of mobilization, i.e. use of these reserves.

When verifying the feasibility of the implementation plan, we will determine whether it corresponds to the planned volume of realization of marketable products and to the planned change in the balances of unrealized products during the year.

To assess the degree of implementation of the sales plan, we summarize the data in Table 4 and compare the planned and actual sales in the planned prices.

So, the under fulfillment of the plan for sales of $2,046,360$ thousand rubles, or $9 \%$, was due to the under fulfillment of the plan for the production of cars. The increase in the balances of unrealized products is 1,056,684.48 thousand rubles. Greater than expected, increased the degree of underfulfillment of the implementation plan by $1,056,684.48$ thousand rubles, or 4\%. The overall impact of the two factors (balance of factors) is:

$-989675.52-1056684.48=-2046360.00$ (thousand rubles) 
Then we analyze the composition of unrealized products and identify the reserves of further increase in sales.

The composition of unrealized products at the end of the year is characterized by the following data.

The Unjustified nature of the following types of unrealized products: 1) superplanned balances of finished products in the warehouse - 263,526.90 thousand rubles; 2) the remains of goods shipped, not paid in time by buyers - 481,951.40 thousand rubles. 3) the remains of goods in safe custody - 2,899.40 thousand rubles.

The elimination of these types, that is, the reduction of finished goods stocks to the established target value, as well as the sale of goods not paid on time and on the custody of the buyers, is a reserve for increasing the volume of sales in the sphere of circulation. The reserve for the LADA GRANTA model will be:

$$
\begin{gathered}
263526,90+481,951.40+2,899.40=748,377.70 \\
\text { (thousand rubles) }
\end{gathered}
$$

At present time, LLC "OAG" attaches great importance to fulfilling the plan of sales of products (rhythmicity). Rhythmicity is the uniform sale of products in accordance with the schedule in the volume and assortment provided by the plan. Violation of the plan leads to a decrease in sales volumes. Irregularity generates downtime of equipment, transport, loss of working hours, the need for overtime workers, worsens all economic indicators: the quality of products decreases; The volume of unfinished production and superplanned remains of finished goods in warehouses are increasing, and, consequently, the turnover of capital is slowing down; Deliveries under contracts are not carried out and the enterprise pays penalties for untimely shipment of production; Untimely revenue comes, etc.

To estimate the rhythm of shipment of products, we use the following indicators:

Coefficient of rhythmicity - Krhythm. Its value is determined by summing the actual specific weights of the sales volume of cars for each period, but not more than their planned level;

The coefficient of variation (Kv) is defined as the ratio of the mean-square deviation from the planned task for a day (ten, month, quarter) to the average daily (average decadal, average monthly, average-non-quarterly) planned shipment of products.

Based on the data in Table 6, we calculate the rhythm of the sale of products.

The coefficient of rhythmicity of sales of products was:

Krht $=29.0+32.0+16.0+15.0 / 100=0.92$

\begin{tabular}{|c|c|c|c|c|}
\hline \multirow[t]{2}{*}{ Quarter } & \multicolumn{2}{|c|}{ Shipment of cars, units. } & \multirow{2}{*}{$\begin{array}{l}\text { Implementation of the plan, } \\
\text { coefficient }\end{array}$} & \multirow{2}{*}{$\begin{array}{l}\text { Share of shipment, in the implementation of the } \\
\text { plan for rhythm,\% }\end{array}$} \\
\hline & Plan & Fact & & \\
\hline First & 23095 & 21267 & 0,921 & 29,0 \\
\hline Second & 25167 & 24091 & 0,957 & 32,0 \\
\hline Third & 12504 & 12231 & 0,978 & 16,0 \\
\hline Fourth & 14421 & 11246 & 0,780 & 15,0 \\
\hline Total & 75187 & 68835 & 0,916 & 92,0 \\
\hline
\end{tabular}

Tab. 6: Rhythm of sales by quarter.

In this period, the plan for the shipment of products is underfulfilled by 6,352 vehicles.

Let's find the coefficient of variation: $(K v=0,35)$.

Thus, sales of products by quarter deviate from the schedule by an average of 35\%.

The carried out analysis of output and sales of products revealed the following results:

a the traditional model for the company is the LADA GRANTA car, whose share in the shipment volume is $94.60 \%$;

- priority markets for LLC "OAG" are the Central, Siberian and Volga federal districts;

- the revealed underfulfillment of the plan for sales of products by $2,046,360$ thousand rubles, or by $9 \%$, was due to the underfulfillment of the plan for the production of cars; $\square$ an increase in the balance of unrealized products is $1,056,684.48$ thousand rubles. Greater than expected, increased the degree of underfulfillment of the implementation plan by 1,056,684.48 thousand rubles, or 4\%;

- unjustified nature of the following types of unrealized products: 1) overplanned balances of finished goods in the warehouse - 263,526.90 thousand rubles; 2) the remains of goods shipped, not paid in time by buyers - 481,951.40 thousand rubles. 3) the remains of goods in safe custody $-2,899.40$ thousand rubles; 


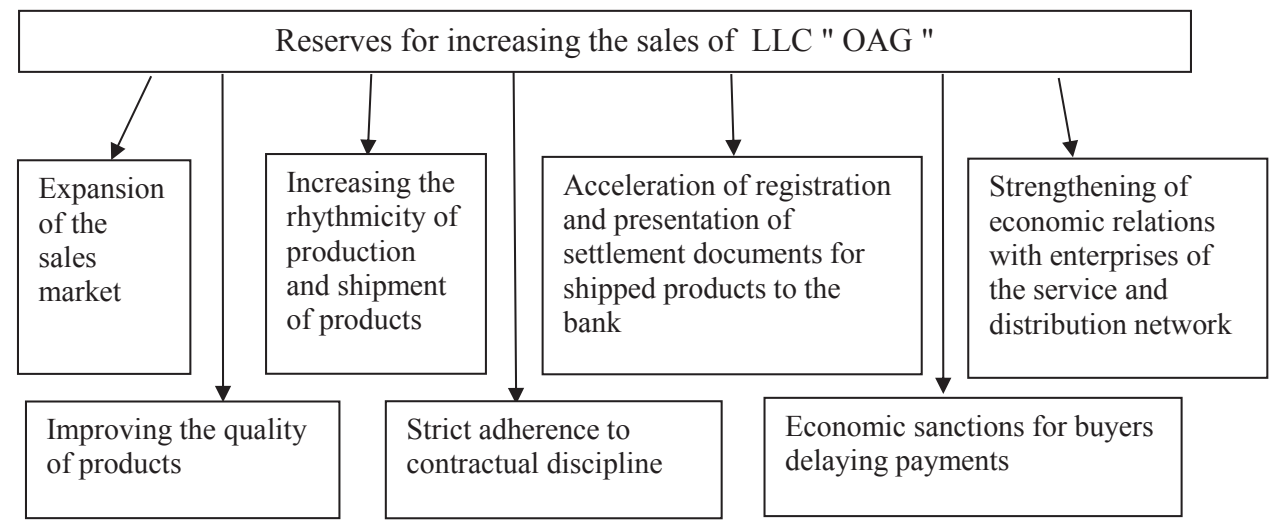

Fig. 1: Proposals for increasing sales and improving economic performance of LLC.

Tab. 7: Economic effect of implementing measures to improve the sale of products.

\begin{tabular}{|c|c|}
\hline $\begin{array}{l}\text { The current state of sales of } \\
\text { products }\end{array}$ & $\begin{array}{l}\text { The result of implementing } \\
\text { measures to improve the sale of } \\
\text { products }\end{array}$ \\
\hline $\begin{array}{l}\text { 1. The quarterly deviation from the } \\
\text { sales schedule by } 35 \% \\
\text { 2. The coefficient of rhythmicity of } \\
\text { sales of products Krht }=0.92 \\
\text { 3. Increase in balances of unrealized } \\
\text { products by 1,056,684. } 48 \text { thousand } \\
\text { rubles. More planned. }\end{array}$ & $\begin{array}{l}\text { 1. Achieve } 100 \% \text { of the sales schedule } \\
\text { 2. Improving the rhythms of the sale of } \\
\text { products by } 8 \% \text { by achieving a planned } \\
\text { rate of rhythmicity Krht }=1.00 \\
\text { 3. Increase in sales volume due to } \\
\text { reduction of balances of unrealized } \\
\text { production by } 748,377.70 \text { thousand } \\
\text { rubles. }\end{array}$ \\
\hline
\end{tabular}

\section{the rhythm of sales of products by quarters deviates from} the schedule by an average of $35 \%$.

Thus, there are the following reserves for increasing the sales of products in OO० OAG:

reserve for the increase in the volume of sales of products due to the reduction of balances of unrealized products in the amount of $748,377.70$ (thousand rubles),

axtension of sales markets to the Southern, Ural, NorthCaucasian, North-Western, Far Eastern regions of the country,

an increase in the rhythm of shipment of products by $35 \%$.

The use of identified reserves is possible through the introduction of a number of activities, as shown in Figure 1. A summary of measures to increase sales is given in Table 7 .

The implementation of these measures will lead to the opening of the company's new development prospects, to increase the competitiveness of products, will allow further expansion of production, create a favorable investment climate, will be the key to successful cooperation with Russian and foreign companies.

\section{References}

[1] Savitskaya G.V. (2017). Comprehensive analysis of the economic activity of the enterprise Textbook. 7 th ed., Pererab. And additional. M.: INFRA-M, 608 p. (Higher education: Bachelor's program). From www.dx.doi.org/10.12737/13326.

[2] Prykina, L. V. (2014). The economic analysis of the enterprise. Textbook. Moscow: Dashkov and Co, . - 256 p.

\section{Biographical notes}

Irina Sokolova: Candidate of Economic Sciences, (born in 1975), The department of accounting and analysis of economic activities, is an Associate Professor at the Kalashnikov State Technical University; Izhevsk State Agricultural Academy, 1997, specialty "Economics and management of agricultural production", qualification-economist, Vyatka State Humanitarian University, professional retraining under the program "State Municipal Administration". Her scientific interests include economic analysis, financial management, economics, investment analysis. Her most relevant publication outputs are: 1) "Innovation activity of the Udmurt Republic at the present stage"; 2) "Increasing the efficiency of potato production and marketing. Problems of economics and management"; 3) "Comprehensive assessment of the efficiency of the use of economic resources"; 4) "Comprehensive analysis of the formation and development of the system of consumer cooperation of the region under market relations". 